Article

\title{
Move Abroad to Move Forward? Self-Assessments of Chinese Students and Undocumented Migrants in France
}

\author{
Florence Lévy ${ }^{1, *}$ and Yong $\mathrm{Li}^{2}$ \\ ${ }^{1}$ EUR Translitteræ, École Normale Supérieure, 75005 Paris, France; E-Mail: florence.levy@ens.psl.eu \\ 2 Triangle Laboratory, École Normale Supérieure de Lyon, 69007 Lyon, France; E-Mail: yong.li@ens-Iyon.fr \\ * Corresponding author
}

Submitted: 6 October 2020 | Accepted: 20 January 2021 | Published: 18 February 2021

\begin{abstract}
Migrants' self-assessments refer to their perceptions of social mobility and positioning. These assessments are often ambivalent and counterintuitive for observers. To overcome contradictory first impressions, we propose a comprehensive approach to migrants' self-assessments that goes beyond the opposition between objective and subjective social mobility and links the transnational context, various social spheres, actors' migratory projects, and their reflexivity. The empirical materials in this article draw on two studies on Chinese migrants in France and confront the trajectories and viewpoints of undocumented migrants and international students. Beyond the differences between their experiences and their legal, economic, and social statuses in France and China, we highlight several common points: First, both groups considered migration a lever to improve their social status. Second, their evaluations link their regions of origin and destination as well as various social spheres. Third, in a transnational context, many factors at different scales influence migrants' subjective self-assessments of the success or failure of their migration. The migrants' assessments can vary according to their emphasis on professional, personal, or family trajectories, or on their choice of reference groups. They are shaped by the complexity of translations of status from one country to another and by rapid social transformation in China. Thus, many interviewees estimate that they are simultaneously in situations of social progression and regression.
\end{abstract}

\section{Keywords}

Chinese migrations; downward mobility; France; highly skilled migrants; self-assessment; social mobility; social sphere; social transformation; undocumented migrants

Issue

This article is part of the issue "Migration and Unequal Social Positions in a Transnational Perspective" edited by Thomas Faist (Bielefeld University, Germany).

(C) 2021 by the authors; licensee Cogitatio (Lisbon, Portugal). This article is licensed under a Creative Commons Attribution 4.0 International License (CC BY).

\section{Introduction}

When we asked Mrs. Yu, an ex-factory worker in China of 45 years who has been earning a living as a sex worker since she arrived in France, if she regrets going abroad, she answered negatively. Even if she is ashamed of this job, she said:

If I had not gone abroad to earn money, I would not have been able to afford to send my daughter to university. For me, this is the most important problem, and I have solved [it]. This is my greatest achievement!

On the opposite side, Mrs. Liu's answer was negative despite her valorised occupation as a sales manager in a French company and a good salary of $€ 5000$. This article draws on migrants' surprising assessments of their mobility. Does migration represent a positive evolution in migrants' lives? This answer is key to understanding actors' decisions and actions-their will to settle down in the host country, learn the local language, and adapt 
to local social norms or, on the contrary, to remain on the margins of society or return to their home country. In this article, we compare the situations of two groups of Chinese migrants living in France since the beginning of the 2000s: international students and undocumented migrants. Beyond the differences of legal, economic, and social status in China and in France, which empirically shape very different migration experiences, we argue that the comparison of skilled and unskilled workers as well as legal and illegal migrants' trajectories and viewpoints is heuristic. It enables us to grasp common dynamics and gain a basic understanding of how constraints might affect the process of migrants' social mobility differently, but also how actors try to bypass these obstacles and exercise their agency.

The empirical materials in this article draw on two original ethnographical studies conducted by the two authors with Chinese migrants who arrived in France in the 2000s. After a discussion on the theoretical and methodological premises of our approach, we present the sociopolitical context of the new Chinese migrations to France. We then compare the Chinese migrants' subjective evaluations and discuss their main dimensions. We conclude with the strengths and contributions of our approach, which illuminate the complex process of migrants' assessment of their social mobility at the transnational scale.

\section{Towards a Comprehensive Approach to Migration Assessment}

Studying social mobility in migration is an aporia: How can we measure downward or upward social mobility when the change of positions occurs in the context of migration between two countries? This amounts to questioning two different and sometimes hardly comparable modes of social hierarchy. Thus, the conventional approach to social mobility presents several difficulties: It is centred on one unique geographic and social space and fails to consider the simultaneous integration of migrants in different countries. It is challenged by the multiplicity of social positions that they can occupy simultaneously in their country of origin and their host country; this classic approach is centred on professional positions (Bertaux \& Thompson, 1997) and underestimates other social spheres and markers that play a role in the negotiation of status; It fails to shed light on the complex ways actors' positions evolve at different social scales; it also does not succeed in grasping the paradoxical mobility of individuals in a situation of upward mobility from a socioprofessional point of view, who yet consider themselves immobile or vice versa (Beaud \& Pasquali, 2017). To overcome these difficulties, over the last twenty years, scholars have increasingly taken notice of the subjective dimension of social mobility and paid attention to the ways individuals live and explain their social trajectories (Attias-Donfut \& Wolff, 2001; Duru-Bellat \& Kieffer, 2006). This enlarges the range of variables and includes in the analysis, for instance, models of social success, individuals' life expectations, and family or group values. It is, thus, heuristic to take the imbrication of objective and subjective dimensions of migrants' mobility into account (van den Berg, 2011). Our analysis draws on this emic viewpoint as we try to understand the various and intertwined social issues at stake in migrants' evaluations of their social mobility during migration.

The transnational approach takes the social spaces of the regions of origin and destination into account as well as the transnational social spaces emerging out of migrant communities (Faist, 2010). Thus, it is important to reconstruct migrants' trajectories across national borders (Bidet, 2018) and consider their status before migration (Engzell \& Ichou, 2020). It helps to understand what is at stake in their social mobility or immobility (Grysole \& Bonnet, 2020). Nieswand (2011) proposed a stimulating transnational methodological perspective to understand how migrants can improve their status in their home country while they remain at the bottom of society in their host country as well as how they take advantage of economic and social remittance to gain more power, wealth, or prestige in their country of origin. Several authors have analysed the complex processes of capital conversion across national boundaries (Bréant, Chauvin, \& Portilla, 2018; Mahut, 2017; Nowicka, 2013; Oso Casas, 2005). Migrants maintain significant ties with their relatives back home and often continue to measure the success or failure of their migration through comparing their situation with the trajectories of their compatriots who remained at home (Lönnqvist, Jasinskaja-Lahti, \& Verkasalo, 2011; Nowicka, 2013, 2014). Thus, social comparison is an important element in the assessment of mobility, and we should pay attention to the relevant others with whom they compare themselves (White, 2012) and analyse their feelings of relative deprivation (Stark \& Taylor, 1989).

Finally, we are in line with scholars who call for considering social transformations in international migration analyses (Aksakal, Schmidt, \& Faist, 2016; Castles, 2010; van Hear, 2010). Social changes in countries of origin or destination may affect social hierarchies and blur migrants' status and social mobility. However, little work has focused on the impacts of social transformations in the home or host country on the experiences of migrants. Oso Casas (2005) showed that the economic advantage of Spanish migrants in France has been taken up by many sedentary Spanish inhabitants after the country's economic boom. Many Hong Kong emigrants to Western countries (Canada and Australia, in particular), after reunification with China in 1984, also found themselves surpassed economically by peers who stayed in Hong Kong (Sussman, 2011). China's rapid economic growth and increasing global prominence represents an emblematic case for studying the link between social transformations and migrants' social mobility. Very few studies have analysed how China's rapid social and economic changes have impacted migrants' experiences, 
and we want to fill this gap. Within a few decades, market transition, industrialization, and urbanization have drastically modified the system of social stratification in China, and this situation tends to challenge the existing literature, which considers social classification systems relatively stable. It also modifies social mobility trends (Zhou \& Xie, 2019). These structural changes in the home country undermine migrants' previously effective modalities of social mobility and old forms of identification (Li, 2020). For instance, international diplomas are no longer an open sesame to upward social mobility but are still important in the social reproduction of upper-middle-class families (Xiang \& Shen, 2009). In this context, migrants may have difficulties converting their migratory experiences into upward social mobility in their countries of origin. Drawing on a qualitative and comprehensive approach, we try to understand the importance that Chinese migrants give to the issues of status and mobility and how their contextual assessment might evolve over time. Thus, the temporal experiences of migrants (Baas \& Yeoh, 2019; Mavroudi, Page, \& Christou, 2017) are at the heart of our analyses, as we link the biographical time of migration to the time of social change and underline the phenomena of synchronization and desynchronization between the tempo of personal life and social change.

\section{Social Transformations in China and New Chinese Migrants to France}

France is the main destination of Chinese migrants in Europe (Ma Mung, 2014), but since the turn of the century, the profile of new immigrants from China has changed drastically. Besides the old chain migration of peasants and small entrepreneurs from Zhejiang, we observe the arrival of individuals without pre-existing ties with migrants settled in France, and particularly large numbers of Chinese students on one hand and illegal economic migrants from Northern Chinese cities on the other. The emergence of these new flows is linked to changes in migration regimes in Europe and in China (Xiang, 2003), but it is also a consequence of the rapid transformations of Chinese society (Lévy, 2015; Pieke, 2007) since the end of the 1990s.

In China, this period was marked by a large set of economic and social reforms, which led to its inclusion into the global capitalist economy. The shutdown of many state-owned enterprises created an unemployment crisis; these ex-employees' belonging to a valorised urban "middle class" was challenged. To dispel the threat of poverty and social exclusion and to maintain a good standard of living for their families, some of them decided to go and remain (illegally) abroad. The collapse of the Maoist welfare system had tremendous consequences on the housing, medical care, and education systems, whose costs rose drastically (Rocca, 2006; Zhang \& Ong, 2008). The increase of university fees since 1995 combined with youth unemployment has created anxiety about the future for the young generation as well as their parents. Education was considered an important social mobility lever. Chinese families have invested huge amounts of money in schooling fees and were ready to send their only children abroad to complete international studies. This strategy was considered an escape from the elitist and costly Chinese education system and a rational investment to meet the requirements of the Chinese labor market (Li, 2016). Thus, at the turn of the century, China experienced an "overseas departure fever" (chuguo re) among illegal migrants and international students.

These two groups of individual migrants arrived at the same time in France and have contributed to changing the face of local Chinese community, as in other countries (Pieke, 2007). There were an estimated tens of thousands of illegal Northern Chinese migrants in the mid-2000s (Gao \& Poisson, 2005). From 1998 to 2003, the number of Chinese students entering France each year increased eightfold, from 825 to 7164 , before stabilizing in the mid-2000s (National Institute of Statistics and Economic Studies, 2005). In the first decade of the 21st century, student and irregular migrations were the two most important modalities of entry for Chinese citizens to France; they were also emblematic of highly desirable and undesirable migration, respectively, for French authorities and local public opinion. Thus, the French government adopted very different treatments toward these two groups of Chinese migrants: On one hand, a policy of repression of illegal flows and clandestine work, on the other hand, a policy of attracting international students (particularly Chinese ones), whose stay after graduation has been encouraged with facilitated access to the French labour market since 2006 (Li, 2019b).

\section{Fieldwork: The Confrontation of Two Studies on Chinese Migrants in France}

This article confronts the empirical material collected during two ethnographic studies realized separately by the co-authors for their doctoral dissertations.

Li (2016) focused on the professional integration of international Chinese students who graduated in France and live in the Haute-Normandie region or île-de-France. Using a life-story approach, he interviewed 45 Chinese graduates during 2007-2016: 23 employees, five researchers, nine entrepreneurs and businessmen, and eight of other statuses (inactive, job seekers, working in liberal professions, etc.). Repeated interviews, observations, and informal contacts allowed the researcher to compare the self-assessment of respondents over time and to better understand their trajectories and subjective mobilities.

The students had migrated in their 20 s to obtain higher education degrees in France. They arrived in France in the early or mid-2000s; 20 out of 45 were women. Some had completed university degrees before their departure from China. Their families were relatively 
affluent, and their parents were civil servants, engineers, administrative staff, entrepreneurs, etc. It should be noted that most international Chinese students in France have no scholarships and rely entirely on their families' support to pay their education fees and living expenses abroad. At the time of the survey, the respondents were between 25 and 36 years old and the average length of their stay in France was seven years.

Florence Lévy's (2015) dissertation focused on the evolution of migration plans of undocumented economic migrants from Northern China living in the Parisian region. Speaking fluent Chinese, she carried out participant observations over the course of 10 years (from 2004 to 2014), collecting information through informal discussions in workplaces, dormitories, places of prostitution, flea markets, and other informal settings. After establishing trust with interviewees, she conducted repeated in-depth interviews in Mandarin with 82 migrants ( 60 women, 22 men). Seventeen were interviewed at regular intervals over a period of three to nine years to observe the evolution of their points of view. This ethnographic methodology and a qualitative and comprehensive approach provide a deep understanding of migrants' agency and rationality as well as their subjective points of view and emotions.

These undocumented economic migrants had migrated in their 40s. They arrived in France between 1998 and 2005 from big cities in Northeast China but also from Tianjin, Shandong, Henan, Hebei, etc. Women represented $70 \%$ of all migrants (Gao \& Poisson, 2005). The educated urban residents highlighted their average living standards in China. They used to work in large enterprises as skilled workers, accountants, salespeople, managers, doctors, etc. As state-owned enterprise employees, they had access to a large welfare system. A majority owned at least one apartment. However, the shutdown of many public companies in the 1990s challenged their belonging to a lower urban middle class in China. Many interviewees explained their decisions to migrate based on fear of losing their jobs and concerns about providing a good standard of living for their families, especially paying increasing university fees for their only child. They decided to go abroad alone with tourist visas, leaving their families in China. They planned to work abroad for a short period before returning to China.

Although resources and statuses in China differed greatly among the two groups, comparing them reveals similar dynamics. All respondents emphasized being part of the urban middle class in China (and thus, its various segments). However, their valued personal or family positions were challenged by the rapid economic and social transformations. They regarded a short migration as a strategic option to resist economic and social competition and downward social mobility in China and to maintain their personal or family rankings in the local social hierarchy. Some even expected to take advantage of emigration to radically improve their social positions in China. The issue of social status and their desire to access social mobility were thus at the core of their migration projects before their departure.

\section{Different Social Status and Common Dynamics}

Exploring their experiences in France also revealed common dynamics between the two groups. These observations forced us to go beyond the statement of their divergent trajectories due to different legal statuses and cultural, economic, or social resources in France.

At the time of the survey, the students were in their early thirties and had graduated from French business schools, engineering schools or universities. They spoke French fluently and had good relationships with locals (friends, ex-schoolmates, neighbours, colleagues, etc.). The employees all had 5-year university degrees, either from a grande école or a university program considered to be of high value. They were digital service engineers, audit managers, accountants, or landscape designers, and most had permanent contracts with French companies. The researchers were all new PhDs or postdocs in natural sciences working in French laboratories. Some had opened their own businesses (Asian grocery, store, restaurant, boutique, travel agency, etc.).

These situations contrast with those of middle-aged undocumented migrants who did not speak French and had no acquaintances to support them upon their arrival in France. After their visa expiry, they became illegal migrants and settled on the margins of local society, relying on Chinese economic migrants' networks. Most of them were employed by Southern Chinese businessmen and families who had established themselves in France earlier. They worked illegally as domestic servants or in construction sites, restaurants, sewing workshops, or warehouses. Others turned to French employers as maids and nurses or worked in massage or beauty parlours, or even as independent ragmen and sex workers.

In both groups, migrants expressed significant disappointment with their living and working conditions in France. The examination of their various professional trajectories shows common impediments in their access to the French job market and professional interactions.

Once graduated, students reported major difficulties finding jobs in France and changing their student cards to professional work permits. During interviews, they explained having accepted wages and positions below their original expectations. Many had taken precarious jobs in small and middle-size companies. They often reported feeling marginalized at work and mentioned forms of everyday racism in their interactions with superiors, co-workers, or clients. Despite their technical qualifications, many female engineers were assigned to communication or customer service tasks, revealing a combined effect of gender and ethnic prejudices. Finally, many testimonies pointed out obstacles in professional advancement and access to management or leadership positions compared to their European colleagues, revealing the effect of a race-based glass ceiling (Li, 2016). 
The undocumented migrants struggled to find resources in France; their illegal migration status barred access to expected jobs and income. They talked extensively about long working hours, low wages, and harsh working conditions. They often underscored important tensions with Southern Chinese employers, who looked down on their professional experience and diplomas from China. They experienced a reverse of the social hierarchy in migration, as they had become dependent on Southern employers, whom they used to disdain in China for their rural status and low education levels (Lévy, 2015). Male and female migrants faced a harsh deskilling and a gendered division of labour in the Parisian Chinese job market. They felt forced to accept unpleasant working conditions. Many tried to shun tensions in this ethnic labour market and work for French employers. Women also relied on gendered and ethnic skills in Chinese massage or beauty parlours. A minority of men and women worked in stigmatized economic sectors as independent sex workers or ragmen, scavenging in Parisian dustbins for goods to sell at flea markets. All interviewees considered illegality a major impediment and desperately tried to get resident permits and access legal and protected working conditions. To attain that objective, many women decided to marry French citizens (Lévy, 2019; Lévy \& Lieber, 2011). Hence, in both groups, we observe processes of professional deskilling and racial, ethnic, and gender discriminations as well as symbolic violence during work interactions. Even if they have access to very different segments of the job market, their trajectories are both shaped by the combined effects of employer discrimination and institutional barriers to the French labour market (Li, 2019b).

\section{Migration Plans and Mobility Assessment}

Except for a few, most migrants had not anticipated these tensions before their departure from China. The sharp contrast with their expectations might explain their disappointment and leads us to pay closer attention to our interviewees' life projects and migration plans. Despite his high income and valued social status, Mr. Zheng, a 43-year-old engineer, had been torn by a feeling of downward social mobility. He left China to enter a highly competitive engineering school in France and boost his professional and economic career in China. During the interviews, he emphasized that in his family, his father, a senior engineer, and his mother, a general practitioner, had always repeated that "you should never be satisfied with yourself; you always have to improve yourself." During the first interview in 2008 , he was very unhappy about working in a small company. He hoped "to enter a large company and go up step by step-first as a technical consultant and then as a project manager, step by step." Ten years later, he seemed to have fulfilled his ambition, having become a software engineer at a large, famous French company. His gross salary increased from 40,000 to 55,000 euros a year, and he enjoyed a comprehensive benefit package as an employee of a large company. Yet, he was bitter and highlighted that he had not been promoted since he joined the company in 2012, despite his tireless efforts. He stated that he would have liked to quit the company and work as a freelancer, but his wife disagreed with him, as she was afraid that it could destabilize the family now that they had children. Being unable to achieve a management position gave him a feeling of intertwined failures and marked a defect of his migration plan. For him, though, it was also a setback regarding his taken-for-granted life trajectory (Festinger, 1954); it represented underperformance regarding his family achievements, as his parents and siblings all had manager positions. The feeling of missing out on life caused an acute midlife crisis for him as someone over 40 years old: "Sometimes I wonder if I'm not too old to change jobs."

This case illustrates the importance of taking actors' migration plans and life expectations into account to understand their assessment of their trajectories. It also upholds the importance of paying attention to the underlying (and often unexplained) social norms that guide their evaluations. A range of qualitative information such as family values, dominant norms, and patterns of social success according to actors' life stages play major roles in actors' reflexivity. All these elements help to understand their counterintuitive evaluations of their mobility.

\section{The Role of the Private Sphere in Mobility Evaluations}

Whereas most quantitative studies on social mobility have focused mainly on professional positions and economic income level, the narratives of the migrants we met in France forced us to expand the scope of possible elements and fields involved in their assessments of their social status and mobility after migration. Actors do take economic indicators into account but also pay attention to a large variety of elements and connect very different social spheres in their assessments, highlighting professional, economic, legal, family, and matrimonial issues. We have also observed that they often compare their situations before and after their migration.

\subsection{Family Issues}

Many undocumented migrants complained about their degrading and exploitative working conditions, explaining that they were "forced to turn to demeaning means of survival" and to work in the sex industry or as ragmen. At the same time, they highlighted their pride in sending economic remittances back home to support their families. Mr. Dong, a former taxi driver in China, was ashamed of earning a living as a ragman in France. He felt very embarrassed when people looked at him while he inspected dustbins in the Parisian street. Still, he stressed his success in being able to purchase a new apartment for his son, who, thanks to this ownership, 
had become a good match. In China, owning a personal apartment is now a prerequisite for entering into marriage for young men.

The harshness of migrants' lives or their downward mobility is less significant than the contrast between their objective trajectories and their subjective assessments of their migration. Taking into account family issues allows us to understand their paradoxical evaluations. For these interviewees, in their 40s, being able to be a good parent is a crucial issue, which was sanctioned by a good reputation in China. It is particularly important for migrant women, who run the risk of being labelled "bad mothers" or "careless women" who have left their children behind. Thus, the fulfilment of their social role in China weighs against the type of economic activities they have access to in France. This achievement from afar compensates migrants' feeling of deskilling and of harsh downward mobility abroad.

Highly skilled migrants also relied on the same logic of balancing different types of situations; they counterbalanced their limited individual achievements in the professional sphere with their good living conditions in Europe. Parenthood very often radically changed the migratory path of qualified Chinese migrants, who were considering henceforth settling in France. They took advantage of their parenting roles to compensate for their meagre career progress and change the meaning of their migration, pointing out that they could offer their children a better living environment in France. They stressed the lower level of pollution in French cities or the advantages of raising their children in a less stressful education system and shunning the high level of competition among students in China. Considering their situation through intergenerational lenses allowed them to reassess their individual migration in a more positive way; it represented a decisive step toward their offspring's future achievements. This long-term family mobility logic, which leaves some room for social mobility, is actually quite common for migrants. It echoes the strategies of North African migrants who face significant deskilling in France but expect that their children will realize their aspiration of mobility (Santelli, 2001). It has also been analysed in the cases of Chinese women who married rural men in Japan; these urban migrants felt stuck in the countryside but hoped that their children would soon move and live in big Japanese cities (Le Bail, 2013).

\subsection{Matrimonial Issues}

Migrants' concerns about their matrimonial status is also decisive in their assessment of their positions in France or China. For Chinese graduates who migrated in their 20 s as singles, the speed of their transition to adulthood was a key element in their judgments and may explain their feelings of having been socially immobile. For them to enter adulthood means essentially to find a job and marry. Such is the case of a male IT engineer whose failure to find a stable female partner in
France echoed his feeling of being stuck in his professional career. He compared his situation with those of his schoolmates in China:

They already have a family, children....In fact, we [the Chinese overseas students] have no advantage over them....We have the feeling that we have ruined our life-wasted our money [and time] in France without getting the slightest result. We are ashamed of ourselves by comparing ourselves with others.

To get married and settle down around 30 years of age represented a crucial challenge for graduate migrants of both sexes, a test of their ability to conform to the dominant biographical model in China: to graduate, find a wellpaid position at a big company, buy an apartment, marry, and have a (male) baby soon after. The expectation to fulfil these normalized life sequences is also a source of distress for young adults in China, but our interviewees pointed out that living abroad represented an additional impediment. First, longer schooling and difficulties in gaining access to employment after graduation delayed their settlement in adulthood, compared to their peers in China. Second, there is a structural mismatch in the matrimonial market in France; skilled Chinese migrants generally sought younger and less skilled Chinese women. However, the gender relationship tended to change in migration situations: Graduated migrant women also had professional ambitions and did not wish to confine themselves to roles as wives and mothers. For both male and female migrants, living abroad made it more difficult to achieve an ideal marriage according to the recent dominant norms in China (i.e., a division of roles in which the husband is the economic provider of the family and the wife takes care of domestic tasks and the education of children; see Raymo, Park, Xie, \& Yeung, 2015). Finally, whereas young people of both sexes felt pressure and frustration in their transition into adulthood, men and women related differently to age norms and non-Chinese partners. Male migrants claimed to have a hard time seducing European women, as the image of Asian men was associated with subordinate masculinity in Europe (Hibbins, 2005; Liu-Farrer, 2017). Chinese women, whose femininity was valorised, did not face the same problem, as they had been successful in the binational marriage market. However, female interviewees did speak about being threatened by the Chinese stigma of shengnü, or leftover women, who are unable to marry before the crucial age of 27 . They received frequent international phone calls from parents or relatives who pressured them to find partners and marry. Female graduates, who were confronted earlier than their male counterparts with this injunction, had stronger feelings that migration delayed their entry into family life in comparison to their peers in China. These gendered impressions of failure in the private sphere influenced interviewees' assessments of their social mobility and explained their mixed feelings about their migration. 


\section{Self-Assessment in a Changing Transnational Context}

In their self-evaluations of their trajectories, the migrants we interviewed asked themselves not only whether they had achieved their initial goals but also whether they were doing better than others. Depending on the context of interaction, migrants can compare themselves with various types of people and groups (White, 2012): citizens from the host country, compatriots and migrants of different origins in the host country, or persons living in their home country. We observed that even if they had lived in France for many years, the interviewees we met attached greater importance to their friends and acquaintances in China. Their relatives, childhood friends, former classmates and colleagues, or neighbours in China often continued to be their main reference groups. This finding is in line with research on social comparison and migration, which has shown that migrants often compare themselves with their peers in their countries of origin to measure the success or failure of their migration (Lönnqvist et al., 2011; Nowicka, 2014; Stark \& Taylor, 1989).

It also corroborates that the graduates and undocumented migrants we met regarded migration as a strategy to better climb the Chinese social ladder and confirms that their initial migration project intrinsically included the idea of return. Therefore, throughout their stay in France, our interviewees constantly projected themselves into the social space of their country of origin. Thanks to communication technologies, migrants remained in contact with their original local communities during their stays abroad. Thus, drawing on comparisons with persons in the same social situations upon their departure, they formed rather precise ideas of their relative evolution (Suls, Martin, \& Wheeler, 2002). This development also enabled migrants to imagine the trajectories they could have developed if they had not left China.

However, testimonies revealed that comparisons with people who still lived in China were often a source of disappointment. Many graduates and undocumented migrants believed that their sedentary peers in China progressed faster than themselves and enjoyed more favourable living conditions. The gap with their peers was cruelly felt, especially when individuals had been in France for a long time. This feeling was not only due to the hazards of personal trajectories but also relied on objective reasons related to macrosocial processes.

\subsection{Life in a Slow Lane?}

One of the peculiarities of the China-to-Europe migratory movement is that the migrants come from a country undergoing rapid transformation. In the first decade of the 2000s, the Chinese GDP more than doubled, entailing consequences for Chinese people's life chances and social mobility. Graduate migrants often reported that their university classmates, who were earning modest salaries when they graduated, saw their incomes more than double within a few years or rose quickly into positions of responsibility; they also mentioned with envy that their schoolmates bought homes in major Chinese cities and became wealthy after a surge in property prices. Such rapid upward mobility could hardly happen in the French context due to a much lower growth rate. Graduate migrants find difficult to evolve in both professional and family domains in France. They have the feeling of being caught in a slow traffic lane. The difference in the paces of social change between China and France is large enough to have an impact on the social trajectories of Chinese migrants.

The rise of the Chinese middle class has occurred while the middle-class positions in developed countries were declining (Milanovic, 2016). This macroevolution between the two countries explains that the comparison between the social statuses of migrants and their non-migrant peers is now turning in favour of the latter, who have been able to take advantage of opportunities for work, promotion, investment, and entrepreneurship at home. Radical changes in education, employment, and housing in China are altering the conditions for reintegration of migrants in their home country and their prospects for return. This situation is very clear in Mr. Zhou's trajectory. In 2003, he came to France to study landscape design, a skill that was extremely rare and in demand in China. After graduating, however, he decided to postpone his return to wait for his wife to finish her studies in France. In 2013, when he wanted to return to China, he found the conditions had changed dramatically. His skill was no longer sought after, as the specialty was being taught in China. The remuneration for a work project had fallen by $80 \%$; during the same period, the price of real estate had soared in his city, and it had become extremely expensive to buy an apartment. Mr. Zhou believed that he missed the right time to return to China. He explained that he had lost all hope of competing with his former college mates who never left China, as they had already obtained director positions and had higher incomes. Thus, he gave up his project of returning to China and has decided to work in France, hoping to someday be able to create his own architectural firm there.

\subsection{The Difficulties of Returning Home Triumphantly}

At the same time, Chinese international students' mobility strategies have been eroded by the rapid devaluation of Western diplomas in China. Such students have bet on the prestige of international diplomas and expected to bypass the fierce competition in the Chinese job market to immediately get managerial positions in large local or international companies in China. During their studies abroad, though, the situation changed in their home country. Over the past 15 years, with the expansion of the Chinese university system, diploma inflation, and the subsequent employment crisis, a foreign degree is no longer sufficient to guarantee an elite position 
for foreign-educated Chinese graduates. Some young Chinese returnees from overseas study are unable to find jobs (Hao \& Welch, 2012; Xiang \& Shen, 2009).

Finally, China's modernization has led to the trivialization of "foreign things." Scholars have shown that with the intensification of the exchange of goods and information between China and the rest of the world, development of mass tourism, and increase in international migratory flows, the Chinese middle classes no longer look at overseas Chinese with the envy and wonder of yesterday (Trémon, 2018). Western living conditions abroad are no longer a desirable prospect for urban and affluent youth in China. Consequently, this new perception of migration and migrants has changed how Chinese migrants evaluate their own trajectories. Hence, many graduate migrants expressed that their trajectories abroad were no longer a source of pride. They reported self-shame and a deep feeling of being stuck and immobile for years. Some were even confronted with identity crises (Li, 2019a).

Many undocumented migrants also reported a feeling of failure in comparing themselves with their acquaintances in China. The value of their earnings in France had declined with the drop in exchange rate between the euro and the yuan, which fell from 10 to eight in a decade. This global context explains that both graduates and undocumented migrants are challenged by the devaluation of their symbolic and economic capital acquired abroad. We observed that they experienced relative deprivation, underlining their feelings that they had missed opportunities in China and that their hard-won progress in France seemed ridiculous compared to their peers' spectacular achievements in China.

Migrants' self-assessment of their social mobility can have a strong impact on their life plans and migration decisions. It might explain the various decisions of undocumented and graduate migrants regarding a possible return to China. The former keep thinking that they will retire in China, while the latter tend to settle down in France. According to them, their progression does not allow them to return to their country of origin triumphantly. Even if they maintain ties with their friends in China, receive moral and financial support from their parents, and make regular trips to their country, they have difficulty transferring their achievements from France to China. In fact, the educational and cultural capital acquired in France cannot be converted into social advancement without their physical return to China. In addition, as young and highly skilled professionals, these Chinese migrants may integrate into French society more easily than undocumented migrants. They do not face language barriers in France, they have many professional and private contacts with locals, and many of them finally build their family lives in France. Gradually, the feeling of losing one's place in the country of origin leads them to focus increasingly on their lives in France (Li, 2020).

\section{Conclusion}

In this article, we have developed a transverse approach for understanding self-assessments by skilled and undocumented migrants of their social mobility and status. If the experiences of migrants of various legal and social categories have often been studied separately, we point out that beyond the obvious differences in their migration trajectories, they are confronted with similar dynamics, which are less visible either in their country of origin or in the host country.

The first contribution of our article is to develop a qualitative and comprehensive approach that allows us to go beyond many preconceived ideas on migrants downward or upward social mobility. We bring to light the fact that migrants often have feelings of experiencing upward and downward mobility (or even immobility) simultaneously. The comprehensive approach helps to go beyond the first impression of actors' paradoxical assessments of their migration and social mobility during migration. Their points of view should be understood according to the specific context of enunciation and depend on the reference groups, spheres of life, and social spaces that migrants considered at the time of the interviews.

The second contribution of our article is to consider simultaneously the reflexivity of actors on their trajectories, the transnational context and various scales of analysis, and the various dimensions and elements involved in the interviewees' evaluations of their migration. We discussed three aspects that reveal the complexity of migrants' assessments: (1) They are carried out in connection with actors' migration projects and based on diachronic comparisons of the ego's situations with living conditions in the past, (2) they intertwine various social spheres (professional, marital, family, residential, legal, etc.) and (3) they put the spaces of the countries of origin and arrival into perspective.

Third, we insist on the need to pay attention to the temporal dimension in the analyses of mobility and migrant assessments. The crossing of the diachronic and synchronic points of view provides a deeper understanding of migrants' self-evaluations that seems contradictory at first. The relationship between time and migration can be seen from several angles: the life cycle and migration path, the transition to adulthood, or the question of rhythm in the transnational context. In the case of Chinese migration to France, migrants are confronted with unequal speeds of social change in the origin and host countries. We suggest that part of migrants' feelings of downgrading may result from this temporal dissonance. This finding implies that time does not extend homogeneously in migrants' transnational social space; this transnational space can be characterized by an increasing desynchronization between the tempo of mobile migrants and the pace of social life in their country of origin. This situation might shape both the migrants trajectories and their subjective evaluations of mobility. 


\section{Acknowledgments}

Florence Lévy wrote this article during a post doctorate fellowship in the project "Emergences of the City of Paris on The Chinese Population in Paris: Identities and Identifications under Transformation" (https://chinoisenidf.hypotheses.org).

\section{Conflict of Interests}

The authors declare no conflict of interests.

\section{References}

Aksakal, M., Schmidt, K., \& Faist, T. (2016). Social transformation and migration: Unveiling the nexus. (COMCAD Working Papers No. 147). Bielefeld: COMCAD.

Attias-Donfut, C., \& Wolff, F.-C. (2001). La dimension subjective de la mobilité sociale [Subjective dimension of social mobility]. Population, 56(6), 919-958.

Baas, M., \& Yeoh, B. (Eds.). (2019). Migration studies and critical temporalities. Current Sociology, 67(2). https://doi.org/10.1177\%2F0011392118792924

Beaud, S., \& Pasquali, P. (2017). Ascenseur ou descenseur social? Apports et limites des enquêtes de mobilité sociale [Upward or downward social mobility? Contributions and limits of social mobility surveys]. Cahiers Français, 383, 19-25. Retrieved from http://www.la-revanche-des-ses.fr/BeaudPasquali-apportsetlimitesdesenquetesdemobilite sociale.pdf

Bertaux, D., \& Thompson, P. (1997). Pathways to social class: A qualitative approach to social mobility. Oxford: Oxford University Press.

Bidet, J. (2018). Déplacements: Migrations et mobilités sociales en contexte transnational [Displacements: Migration and social mobility in transnational context]. Actes de la Recherche en Sciences Sociales, 225(5), 67-82.

Bréant, H., Chauvin, S., \& Portilla, A. (Eds.). (2018). Les migrations internationales à l'épreuve du capital social [International migrations and social capital]. Actes de la recherche en sciences sociales, 5(225), 8-13.

Castles, S. (2010). Understanding global migration: A social transformation perspective. Journal of Ethnic and Migration Studies, 36(10), 1565-1586.

Duru-Bellat, M., \& Kieffer, A. (2006). Les deux facesobjective/subjective-de la mobilité sociale [Objective and subjective, the two sides of social mobility]. Sociologie du Travail, 48(4), 455-473.

Engzell, P., \& Ichou, M. (2020). Status loss: The burden of positively selected immigrants. International Migration Review, 54(2), 471-495.

Faist, T. (2010). Towards transnational studies: World theories, transnationalisation and changing institutions. Journal of Ethnic and Migration Studies, 36(10),
1665-1687.

Festinger, L. (1954). A theory of social comparison processes. Human Relations, 7(2), 117-140.

Gao, Y., \& Poisson, V. (2005). Trafficking and exploitation of Chinese migrants in France. Geneva: International Labour Organisation.

Grysole, A., \& Bonnet, D. (Eds.). (2020). Mobilités de classe [Class mobility]. Paris: Karthala.

Hao, J., \& Welch, A. (2012). A tale of sea turtles: Job-seeking experiences of hai gui (high-skilled returnees) in China. Higher Education Policy, 25(2), 243-260.

Hibbins, R. (2005). Migration and gender identity among Chinese skilled male migrants to Australia. Geoforum, 36, 167-180.

Le Bail, H. (2013). L'envolée des mariages mixtes: Une trajectoire féminine de migration [The increase of mixed marriages: A female migration trajectory]. Hommes \& Migrations, 1302(2), 74-75.

Lévy, F. (2015). L'évolution des projets migratoires dans l'espace transnational. Une ethnographie des migrants de Chine du Nord à Paris [Reconfiguration of migratory plans in the transnational space. An ethnographic study of Northern Chinese Migrants in Paris] (Unpublished Doctoral dissertation). Fondation France-Japon de l'EHESS, France.

Lévy, F. (2019). 'Il me donne des papiers, je le sers.' Dons et contre dons dans les couples franco-chinois ['He has given me document, I serve him.' Gift exchange within franco-chinese couples]. Journal des Anthropologues, 2019(156/157), 83-104. https://doi.org/ 10.4000/jda.8078

Lévy, F., \& Lieber, M. (2011). Sex and emotion-based relations as a resource in migration: Northern Chinese women in Paris. Revue Française de Sociologie, 52, 3-28. Retrieved from https://www.cairn.info/ revue-francaise-de-sociologie-1-2011-5-page-3.htm ?contenu=article

$\mathrm{Li}, \mathrm{Y}$. (2016). Condamnés à réussir. Insertion professionnelle des diplômés chinois en France, nouvelles dynamiques migratoires et identitaires [Condemned to succeed. Professional integration of Chinese graduates in France, new migratory and identity dynamics] (Unpublished Doctoral dissertation). Université de Rouen, France.

Li, Y. (2019a). The identity crisis of Chinese graduates in France. In Y. Liu \& S. Wang (Eds.), Chinese immigrants in Europe: Image, identity and social participation (pp. 101-126). Berlin: De Gruyter.

Li, Y. (2019b). La confrontation des diplômés chinois au marché du travail Français. Une insertion incertaine? [The confrontation of Chinese graduates with the French job market: An uncertain integration?]. Connaissance de L'emploi, 145. Retrieved from https://ceet.cnam.fr/publications/connaissance-del-emploi/la-confrontation-des-diplomes-chinoisau-marche-du-travail-francais-une-insertionincertaine-1050221.kjsp 
Li, Y. (2020). Le paradoxe de la mobilité. Les évaluations subjectives des trajectoires postuniversitaires des diplômés chinois en France [The paradox of mobility. Subjective evaluations of the trajectories of Chinese graduates in France]. Migrations Société, 180(2), 97-112.

Liu-Farrer, G. (2017). From Asia with money: The emigration of the wealthy. In G. Liu-Farrer \& B. Yeoh (Eds.), Routledge handbook of Asian migrations (pp. 128-138). London and New York, NY: Routledge.

Lönnqvist, J.-E., Jasinskaja-Lahti, I., \& Verkasalo, M. (2011). Personal values before and after migration: A longitudinal case study on value change in IngrianFinnish migrants. Social Psychological and Personality Science, 2(6), 584-591.

Ma Mung, E. (2014). La diaspora Chinoise en France [Chinese diaspora in France]. In S. Weber \& $\mathrm{M}$. Poinsot (Eds.), Migrations et mutations de la société Française (pp. 121-129). Paris: La Découverte.

Mahut, D. (2017). Le déclassement dans la migration. Ethnographie d'une petite bourgeoisie bamakoise installée à Paris [Downward social mobility in migration. Ethnography of Bamako petty bourgeoisie settled in Paris]. Paris: L'Harmattan.

Mavroudi, E., Page, B., \& Christou, A. (2017). Timespace and international migration. Cheltenham: Edward Elgar Publishing.

Milanovic, B. (2016). Global inequality: A new approach for the age of globalization. Cambridge, MA: The Belknap Press of Harvard University Press.

National Institute of Statistics and Economic Studies. (2005). Fiches thématiques sur le flux d'immigration [Thematic fact sheets on immigration flows]. National Institute of Statistics and Economic Studies. Retrieved from https://www.insee.fr/fr/statistiques/ 1371777

Nieswand, B. (2011). Theorising transnational migration: The status paradox of migration. New York, NY: Routledge.

Nowicka, M. (2013). Positioning strategies of Polish entrepreneurs in Germany: Transnationalizing Bourdieu's notion of capital. International Sociology, 28(1), 29-47.

Nowicka, M. (2014). Successful earners and failing others: Transnational orientation as biographical resource in the context of labour migration. International Migration, 52(1), 74-86.

Oso Casas, L. (2005). La réussite paradoxale des bonnes Espagnoles de Paris: Stratégies de mobilité sociale et trajectoires biographiques [The paradoxical success of Spanish domestic workers in Paris: Social mobilities strategies and biographical trajectories]. Revue
Européenne des Migrations Internationales, 21(1), 107-129.

Pieke, F. N. (2007). Editorial introduction: Community and identity in the new Chinese migration order. Population, Space and Place, 13(2), 81-94.

Raymo, J. M., Park, H., Xie, Y., \& Yeung, W. J. (2015). Marriage and family in East Asia: Continuity and change. Annual Review of Sociology, 41, 471-492.

Rocca, J.-L. (2006). La condition Chinoise: Capitalisme, mise au travail et résistances dans la Chine des réformes [The Chinese condition: Capitalism, work and resistance in reform China]. Paris: Karthala.

Santelli, E. (2001). La mobilité sociale dans l'immigration: Itinéraires de réussite des enfants d'origine algérienne [Immigration social mobility: Success trajectories of Algerain origin's children]. Toulouse: Presses Universitaires du Mirail.

Stark, O., \& Taylor, J. E. (1989). Relative deprivation and international migration. Demography, 26(1), 1-14.

Suls, J., Martin, R., \& Wheeler, L. (2002). Social comparison: Why, with whom, and with what effect? Current Directions in Psychological Science, 11(5), 159-163.

Sussman, N. M. (2011). Return migration and Identity: A global phenomenon, a Hong Kong case. Hong Kong: Hong Kong University Press.

Trémon, A.-C. (2018). Sociodicies of (im)mobility: Moral evaluations of stasis, departure and return in an emigrant village (Shenzhen, China). Mobilities, 13(1), 157-170.

van den Berg, M. (2011). Subjective social mobility: Definitions and expectations of "moving up" of poor Moroccan women in the Netherlands. International Sociology, 26(4), 503-523.

van Hear, N. (2010). Theories of migration and social change. Journal of Ethnic and Migration Studies, 36(10), 1531-1536.

White, J. (2012). Parallel lives: Social comparison across national boundaries (LEQS Paper No. 47). London: London School of Economics.

Xiang, B. (2003). Emigration from China: A sending country perspective. International Migration, 41(3), 21-48.

Xiang, B., \& Shen, W. (2009). International student migration and social stratification in China. International Journal of Educational Development, 29(5), 513-522.

Zhang, L., \& Ong, A. (Eds.). (2008). Privatizing China: Socialism from afar. Ithaca, NY: Cornell University Press.

Zhou, X., \& Xie, Y. (2019). Market transition, industrialization, and social mobility trends in postrevolution China. American Journal of Sociology, 124(6), 1810-1847. 


\section{About the Authors}

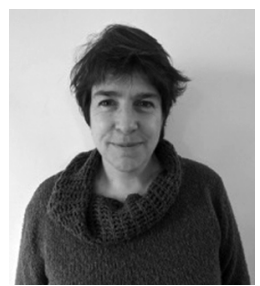

Florence Lévy is a Socio-Anthropologist. She is a postdoctoral fellow at École Normale Supérieure in Paris. She speaks fluent Mandarin and holds a PhD in Sociology from the EHESS in France and Neuchâtel University in Switzerland. Her research revolves around three main topics: migration studies, gender studies, contemporary urban China. She has conducted a lot of research on Chinese migrations in Europe. Her current interest focuses on the negotiations of multiple identities and social statutes in China and in France by Chinese migrants.

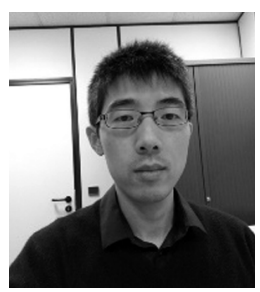

Yong $\mathbf{L i}$ is a Sociologist and Post-Doctoral Fellow at the Triangle Laboratory, École Normale Supérieure de Lyon, France. He is research coordinator in the International Advanced Laboratory "Post-Western Sociology in Europe and in China" at ENS Lyon and Chinese Academy of Social Sciences. He is also a Fellow of the French Collaborative Institute on Migration. His research interests include student mobility, career paths of skilled migrants, experiences of discrimination and racism of people of Asian origin in France. 